\title{
THE ELIMINATION OF $\mathrm{CO}_{2}$ IN CERTAIN METABOLIC DISORDERS (PRELIMINARY NOTE).
}

\author{
By I. Walker Hall, Assistant Lecturer on Pathology in \\ Owens College, Manchester.
}

From Carolinska Institutet, Stockhoim.

The division of the urinary purins into "exogenous" and "endogenous," and the probability that their daily excretion represents only about 50 per cent. of the amount ingested with the food or preformed in the body, lend an additional interest to the precise action of these substances on the organic functions $\left(^{1}\right)$. In many diseases the purin bodies are present in excess in the blood and tissues, and by some are supposed to play a direct rôle in the causation of nephritis. In rabbits, after continuous injection, they appear to induce structural liver changes $\left({ }^{2}\right)$, and they are found in excessive quantities in the urine of patients suffering from diseases of the liver or disorders of general metabolism. In relation thereto, through the kindness of Professor Johansson, I have been enabled to make the following experiments on the elimination of $\mathrm{CO}_{2}$ after the ingestion of certain purin bodies. In December 1900, Professor Robert Tigerstedt very kindly granted my request to be allowed to use the Sondén-Tigerstedt $\left({ }^{3}\right)$ chamber for this purpose, but it was only in 1901 that I was able to spare the time necessary for the journey, etc., and in the meantime Helsingfors had called Tigerstedt to fill its vacant Chair in Physiology.

In 1859, Edward Smith $\left({ }^{4}\right)$ and Hoppe Seyler found that tea and coffee, which contain the methyl-purin "caffeine," caused an increased output of $\mathrm{CO}_{2}$. The apparatus employed consisted of a face mask connected by rubber tubes with the absorptive media. The method was trying and tiring, and gave abnormal results. Levén in 1868, Giraud in 1881, and Parisot in $1890\left(^{5}\right)$ observed that the administration of caffeine to animals caused acceleration of the respiratory movements, but that after toxic doses respiration ceased before the heart was arrested. It is now generally conceded that caffeine indirectly affects metabolic processes and causes slight increases in the excretion of urea and $\mathrm{CO}_{2}$. Little evidence, however, exists as to the action of the purin nucleus in this respect, or as to the portion of the caffeine molecule which is responsible for the effect produced. In 
addition, the old experiments were made with tea and coffee, which contain aromatic bodies capable of producing increased respiratory movements, and the more recent studies in which caffeine itself has been used, have been made upon animals.

The subjects of experiment rose about 7.30 A.M., walked an English mile, and still fasting, entered the Sondén-Tigerstedt respiration chamber about 8.30 A.x., and lay absolutely still upon a mattress for thirty minutes, covered only with a light felt rug. One sample of air was taken five minutes after entry and another thirty-five minutes later. The temperature and pulse rate were observed at the commencement and at the close of each experiment. The analyses were made with a Sondén-Peterson's apparatus.

\section{W. H. (of Manchester).}

November 18, 1901.

8.0 A.M. $0.5 \mathrm{grm}$. caffeine natr. benz. (contains $0.25 \mathrm{grm}$. pure)

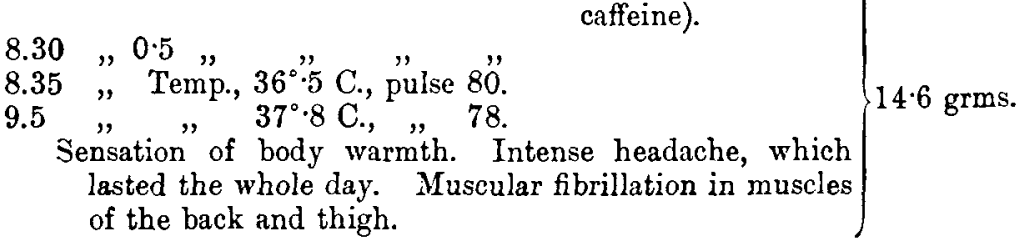
$\mathrm{CO}_{2}$

November 19.

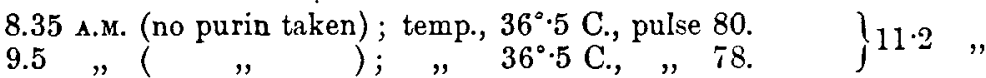

November 20.

7.30 A.M. 0.25 grm. hypoxanthin in alkaline solution.

8.15 " 0.25 " Temp., $36^{\circ} \cdot 5$ C., pulse 76

8.50 " " , $36^{\circ} \cdot 5 \mathrm{C}$., $" 76$.
whole body.

November 26.

7.45 A.M. 0.25 grm. uric acid partially dissolved in alkaline

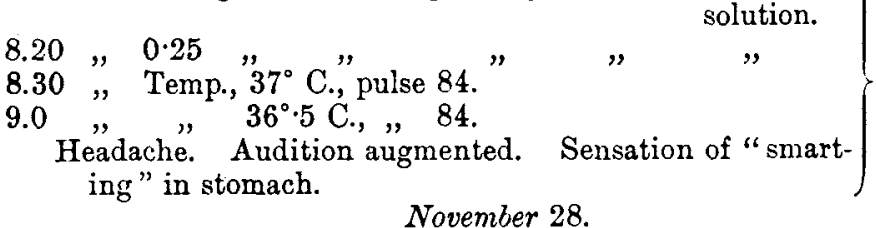

whole body.

7.45 A м. 0.25 grm. uric acid partially dissolved in alkaline

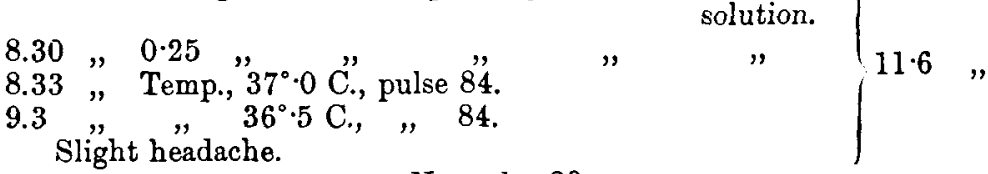

November 29.

7.45 A.M. $0.5 \mathrm{grm}$. caffeine natr. benz.

8.15 " 0.5 " Temp., $36^{\circ} \cdot 6$ C., pulse 84 .

$8.56 \% 36^{\circ} .5$ C., ,, 72.

Fulness in head. Confused ideas. Loss of muscular sense. 
Novemler 30.

7.45 A.M. $0.5 \mathrm{grm}$. uric acid (taken as sodium urate).

$8.15,0.5,, ", \quad$ ( ).

8.35 " Temp. $36^{\circ} \cdot 8^{\prime C}$ C., pulse 90 .

$9.5 \quad " \quad, 36^{\circ} \cdot 5 \mathrm{C}$., " 76 .<smiles>CCC(C)C(C)C(C)=O</smiles>

Dr. Friherre A. C. (of Finland).

$\left.\begin{array}{c}\text { Normal "rest" values. } \\ ", ", "\end{array}\right\}$ No purin taken. $\quad\left\{\begin{array}{cc}9 \cdot 8 & , \\ 10 \cdot 3 & " \\ 10 \cdot 8 & "\end{array}\right.$

7.30 A.M. 0.5 grm. caffeine natr. benz.

$\begin{array}{lll}8.0 & 0.5 & \\ 8.5 & \text { " Temp., } 36^{\circ} .1 \mathrm{C} \text { C., pulse } 60 \text {. }\end{array}$

$8.35, ", \quad 36^{\circ} \cdot 1$ C., , 60 .

Slight surface warmth. "No headache.

November 25.

7.30 A.M. 1 grm. caffeine natr. benz.

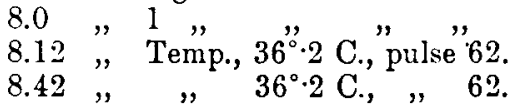

Headache. Abdominal warmth. Diarrhœa in the later part of the day.

Professor S. (Stockholm).

(No purin taken.)

December 5.

8.25 A.M., Temp., $36^{\circ} \cdot 8$ C., pulse 56 .

$8.55, \quad, \quad 36^{\circ} \cdot 8$ C., " 56.

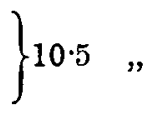

December 7 .

7.55 A.x. 0.5 grm. caffeine natr. benz.

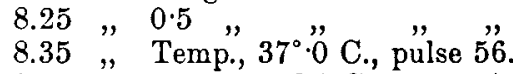

9.5 " " $37^{\circ} \cdot 1 \mathrm{C.}$, , 57 .

Audition slightly augmented. warmth. No headache.

(The samples of air were taken by Vaktmästare Jarl during my experiments in the respiration chamber, and the analyses were controlled by Cand. Phil. Fröken Rosenberg. To both I am much indebted.)

These results show that my early morning $\mathrm{CO}_{2}$ excretion is about 11 grms. per half hour. The values of Dr. C. and Professor S. are somewhat lower. With Professor S. and myself caffeine caused an increased production of $\mathrm{CO}_{2}$ in average doses, but an almost toxic quantity was necessary to produce any effect upon Dr. C. Pure caffeine thus appears to incite increased elimination of $\mathrm{CO}_{2}$, but acts differently upon various individuals. Hypoxanthin, the monoxy-purin, and uric acid, the trioxy-purin, yielded negative results. The chemical constitution of these bodies suggested their inactivity in this respect, but the observations possess an additional value, in that they indicate 
the limited rôle of the purin nucleus, and allow us to ascribe the effects of caffeine upon respiration to its methyl groups. As, during its passage through the body, caffeine losses some of its methyl groups, but is partly excreted as methyl-purin, the manner in which these groups are liberated from the purin-nucleus may determine the extent of stimulation effected. There is no evidence at present to show the results-if any-of the presence of the entirely demethylated purin. It is significant that although the percentage of urinary methyl-purin varies directly but inversely with the quantity ingested, yet the uric acid excretion is almost unaltered ( $\left.{ }^{1}\right)$. Apparently, therefore, about $60-70$ per cent. of the caffeine taken increases the work of the metabolic organs in the oxidation of its purin nucleus to urea or bodies intermediate between uric acid and urea. In these experiments, the action of uric acid was somewhat irregular. On the first occasion, when the uric acid was only partially dissolved, there was a sensation of warmth in the alimentary canal, which, apart from the intense headache, would be sufficient to account for the rise obtained. There was no headache on the second day, but the abdominal sensations were present. For the third experiment, the uric acid was completely dissolved in 340 c.c. of $\mathrm{Na}_{2} \mathrm{CO}_{3}$ solution, and neither headache nor other symptoms interfered with quiet respiration and general comfort. Of course the possibility of "tolerance" is to be remembered.

The sodium benzoate salt of caffeine is extremely soluble, and it was selected in preference to the less easily absorbed pure caffeine. That the other substances were duly absorbed appears from the following records :-

November 21, 7.30 A.M.-Urine passed.

8.15. A.M. $-1: 0.5$ grm.; hypoxanthin (0.20 purin nitrogen) taken.

\begin{tabular}{|c|c|c|}
\hline $\begin{array}{l}10 \text { A.M. }-12 \text { NOON } \\
12 \text { NOON-3 P.M. } . \\
3 \text { F.M. }-7.30 \text { A.M., Nov. } 22\end{array}$ & $\begin{array}{l}\text { Urine. } \\
415 \text { c.c. } \\
100, " \\
650,\end{array}$ & $\begin{array}{c}\text { Purin Nitrogen } \\
0.1227 \\
0.0792 \\
0.1560\end{array}$ \\
\hline & 1166 c.c. & 0.3579 \\
\hline
\end{tabular}

November 27, 7.30 A.M.- Urine passed.

8.A.M. -0.5 grm. uric acid $(0.166$ purin nitrogen) taken.

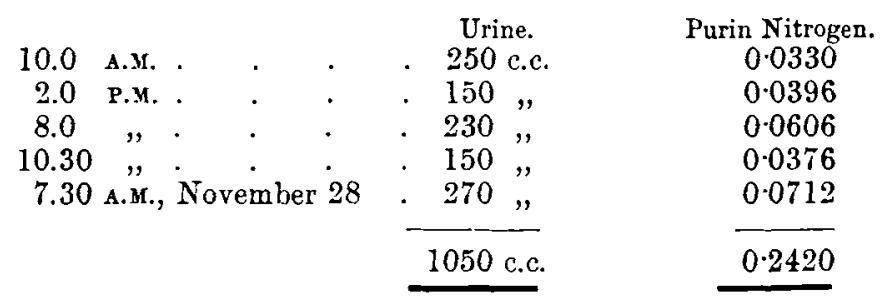

The results of metabolism experiments to be published later show that my endogenous purin excretion is 0.1625 purin nitrogen per 
twenty-four hours. During these experiments purin free food was eaten, with the exception of 300 grms. of veal on the day when hypoxanthin was taken. This quantity of veal yields as urinary purin 0.075 purin $N$. Therefore $0.1625+0.075=0.2375$, the amount of purin nitrogen of endogenous origin plus that from the veal. The remainder, $0.3579-0.2375=0.1204 \mathrm{~N}$., was thus directly due to the hypoxanthin ingested. As the nitrogen of 0.5 grms. hypoxanthin $=0.200$, it will be seen that 60 per cent. of the hypoxanthin was voided in the urine during the twenty-four hours. When uric acid was taken the food was entirely purin free, but was of sufficient caloric and nitrogenous content. As the endogenous purin excretion was 0.1625 , the difference of $0.0795(0.2420-0.1625)$ was due to the uric acid ingested. $0.5 \mathrm{grm}$. of uric acid contains 0.1666 purin N., and therefore $47 \cdot 7$ per cent. was excreted during the following twenty-four hours. The remainder in each case was probably excreted as urea $\left({ }^{6}\right)$. The rapidity of the absorption and excretion in these instances is remarkable, and its practical application will be discussed in a later paper.

The introduction into a healthy body of large quantities of substances formed during the usual metabolic processes, and representing an excess of imperfectly metabolised substances in the blood stream, neither depresses nor increases the normal elimination of $\mathrm{CO}_{2}$. The "metabolites" cause, however, increased activity of those metabolic organs, which complete the processes necessary for their early excretion. It is possible that at first the excess of uric acid may indirectly increase the output of $\mathrm{CO}_{2}$. But it is probable that carbohydrate metabolism is not affected in the early stages of imperfect metabolism, nor is otherwise than almost normal in the usual metabolic disorders.

If caffeine is employed as a cardiac stimulant or with the view to promote $\mathrm{CO}_{2}$ elimination, the work thrown upon the tissues to ensure its excretion should be remembered. For its diuretic action, it might, in the treatment of the symptoms of disordered metabolism, be replaced by urea, which is largely used in Sweden, and merits its employment as well from a scientific standpoint as from the results it produces.

\section{REFERENCES.}

1. Burian und Schur . . . Arch. f. d. ges. Physiol., Bonn, 1901, Bd. lxxxvii. S. 239 ; 1900 , Bd. Ixxx. S. 309. Sivén, Skandin. Arch. f. Physiol., Leipzig, 1900, Bd. x. S. $123 . \quad$ Krüger und Schmidt, Ber. $d$. deutsch. chem. Gesellsch., Berlin, 1899 , Bd. xxxii. S. 2677,3336 .

2. W. HALL . . . . . Dissertation, "Purin Bodies," 1902 ; and Arch. f. exper. Path. u. Pharmakol., Leipzig, 1902. In the Press. 
3.

Details of this, the largest existent respiration chamber, are given in the Skandin. Arch. f. Physiol., Leipzig, 1896, Bd. vi.

4. Edward Smith . . . . Proc. Roy. Soc. London, 1859, vol. ix. p. 611 ; Lancet, London, 1859 , vol. i. p. 216.

5. Parisot . . . . . . . "Étude de l'action de la caffeine sur les functions motrices," Paris, 1890.

6. Swain, R. E. . . . . . Am. Journ. Physiol., 1901, vol. vi. p. 38 ; vide also $\mathrm{W}$. Hall (2). 